\title{
Streaming the Battlefield A Theory of the Internet's Effect on Negotiation Onset
}

\author{
First Lieutenant Anthony Patrick, USMC
}

\begin{abstract}
This article explores the effects of social media penetration and internet connectivity on the likelihood that parties within a conventional intrastate conflict will enter negotiations. The proliferation of advanced information communications technologies, coupled with violent political collective action, calls for further examination of how these variables intertwine to affect conflict patterns. Beginning with a discussion on communications technology and the bargaining model of war, the author presents a theoretical model that seeks to create a foundation that can be used for future empirical testing.
\end{abstract}

Keywords: negotiation onset, intrastate war, internet, communication technology

\section{Introduction}

he character of international competition has evolved significantly over the past 10-15 years. During the Cold War era, most conflicts were either intrastate wars with a hegemonic power (the United States or the Soviet Union) backing a certain side against the local proxy force for the other power. Military interventions were common during this time frame. In the aftermath of the 11 September 2001 (9/11) terrorist attacks and the fallout from the U.S.-led Global War on Terrorism, battlefield deaths from intrastate wars increased in certain parts of the globe, while other areas saw continued spillover

1stLt Anthony Patrick is currently a graduate student at the University of North Carolina Wilmington enrolled in the Conflict Management and Resolution Program. He is an active duty intelligence officer in the U. S. Marine Corps. His past work has focused on low-intensity conflict and national security policy. 
from the conflicts that defined the late twentieth century (e.g., Revolutionary Armed Forces of Colombia [Fuerzas Armadas Revolucionarias de Colombia, or FARC] in Colombia). ${ }^{1}$

The international playing field has begun to shift to a multipolar world, with nations such as Iran, Turkey, Russia, and China showing greater ability and willingness to participate in conflicts away from their borders either through unilateral or multilateral actions. ${ }^{2}$ Support can be provided through financial aid, intelligence sharing, logistical support, weapons transfers, diplomatic cover for operations, and direct military intervention. Some of these conflicts have taken on aspects of earlier Cold War-era contests, with major regional powers backing opposing sides in an intrastate war. ${ }^{3}$ These more powerful proxies are operating with foreign backing in a conventional manner, with lines of control more analogous to interstate conflict than what has been observed in conflicts such as Iraq and Afghanistan. ${ }^{4}$

As these conflicts have evolved during the last $10-15$ years, so has the communications infrastructure used by all sides in these conflicts. Actors are more connected than ever before to local, regional, and global systems through the internet. These advanced information communications technologies (ICTs) have proliferated across the globe, with an estimated 4.6 billion internet users active today on all continents and in all countries. ${ }^{5}$

Pioneering scholarship within the field of ICTs and their interplay with political violence blossomed in the early 2010s, with work covering broad theories, which then narrowed down to specific empirically testable hypotheses. While these works cover a wide range of topics, a gap in the literature has been identified concerning how ICTs affect the likelihood of negotiations. Specifically, this article examines how social media penetration and internet connectivity affect the likelihood of kinetic combatants entering negotiations within a specific time frame.

Using the information-centric approach to warfare, the author will argue that the combination of social media penetration and internet connectivity helps combatants narrow the information gap that exists between them. Combating parties can monitor each other's social media accounts and independent reporters to gather information about their opponent, increasing their situational awareness. The pace of these conventional-style intrastate wars, combined with widespread access to advanced ICTs, means that the cycle of battlefield information reaching combatants is increasing exponentially. This in turn helps the combatants recognize the battlefield realities. Once each side has an accurate picture of the capabilities and limitations of the opponents, they then adjust their war goals to line up with what they could reasonably extract from the opponent at a certain cost. Once this calculation is complete, actors 
can then make the decision to enter negotiations faster than what has been the historic norm.

This research can assist policy makers in two main ways. First, it can assist conflict forecasters in understanding what factors may influence the progression of a conflict. If they can obtain a solid grasp of the information space that combatants are operating in, they can begin to better understand why combatants are taking a certain course of action within the conflict. Second, knowing how information flow affects negotiation onset could aid conflict managers in identifying low-cost interventions that could shorten conflict duration. These interventions, coupled with additional methodologies, could help reduce the cost of conflict, both in terms of financial cost and lives lost.

This article establishes a theoretical analysis of the effects of ICTs on the likelihood of negotiation onset within the context of interstate wars that take on conventional characteristics. Next, the information-centric approach to warfare will be discussed in depth. In the fourth section, the author will introduce the bargaining model of war. Taking all this information into account, the author will then introduce an explanatory theory of how advanced ICTs affect the likelihood of negotiations.

\section{ICTs' Effect on Armed Conflict}

The last two centuries has seen a rapid growth in humanities' ability to quickly communicate larger volumes of information across ever-increasing distances. The introduction of the telegraph made it possible for people to quickly pass messages across the Atlantic, drastically reducing the time for a recipient to get a message. The telephone made instant voice point-to-point communications possible, redefining how groups within society interact. The post-World War I years saw political movements, cultural icons, and companies expand their reach with the introduction of the radio, creating for the first time in human history readily available point to mass communication systems. During World War II, millions of citizens received battlefield updates through easy access to film, which expanded further in the postwar era with the widespread introduction of television.

While this growth is substantial, it pales in comparison to the growth in information sharing the world has experienced in the last 30 years. The combination of cell phone technology, social media, and the internet has made it possible for point-to-point and point-to-mass communications of large volumes of information from almost anywhere in the world. Both endogenous and exogenous connections have in many ways brought aspects of the human experience to our fingertips.

A large body of research demonstrates the connection between ICTs and 
collective action. Linkages formed by ICTs reduce the cost for mobilization. ${ }^{6}$ This is in line with theories proposed by other scholars, pointing out that a central determinant to collective action is the mobilization cost imposed on leaders. ${ }^{7}$ ICTs help a group by allowing it to exchange a greater volume of information with more of its members over a shorter period of time. Amplifying this effect is the disaggregated nature of modern-day ICTs. Wireless devices make it possible for decentralized groups to quickly mobilize en masse.

There are numerous examples of ICTs being used for political collective action in various localities across the globe. Social media has been used to mobilize protesters in Russia, with the most significant effects being observed in areas where one social media site holds a monopoly over local accounts. ${ }^{8}$ At the time of writing, Nexta, a social media channel in Belarus, is using WhatsApp to organize weekend protests against the Belarusian government from Poland, mobilizing tens of thousands and directing them to specific government-owned properties from hundreds of miles away. ${ }^{9}$

This mobilization can also be used toward violent collective action, which is a subset of political collective action. Various studies have examined the relationship between violence and the proliferation of ICTs, demonstrating both positive and negative effects. ${ }^{10}$ In their flagship work within the field, Jan $\mathrm{H}$. Pierskalla and Florian M. Hollenback demonstrate empirically that cell phone coverage increases violent activity within the context of intrastate violence. ${ }^{11}$ The cycle of violence is expedited through the use of instant communication through ICTs to disaggregated networks, allowing actors to communicate directives to specific targets faster than ever before. ${ }^{12}$ This trend is further observed by the work of Catie Snow Bailard, who narrows down the unit of analysis to focus on violent collective action between specific ethnic groups. ${ }^{13}$ The author shows (with an expanded data set) that the introduction of mobile cell technology increases the probability that groups will engage in conflict with their government. A unique finding by Bailard shows that this effect is dampened in regions with increased access to landline communications. Municipalities that have robust landline access already have the ability (albeit not mobile) for point-to-point communication. Thus, the introduction of cell phone access does not change a citizen's ability to communicate directly with others within their community. A community that relies solely on radio communication (point to mass) will see a greater effect from the introduction of cell phones than one that relies more on landline connectivity. This implies that the true increase comes from the shift to instant mobile point-to-point communication through cell phones and internet access and not just the introduction of pointto-point communication.

Cellular communications through $3 \mathrm{G}$ and $4 \mathrm{G}$ technologies allow users to access the internet and thus social media platforms. The evolution of social 
media is one of the most unique advances in how we communicate. While the radio introduced point to mass communication and the phone perfected point-to-point communication, social media allows a user to communicate both vertically and horizontally throughout society. Sites like Twitter and Facebook allow a user to share information within a closed group of followers or friends (horizontal) who can then instantly take that information and share it with out-of-group members who were not directly connected to the initial user (vertical). This expands both the number of nodes within a system an individual can influence as well as the speed of which that influence can spread.

Since this communication can originate from the masses, it challenges the historic control political elites have had on the information sphere. The use of segmented and encrypted networks creates a more diverse information environment, especially in communities where the central authorities lack enforcement mechanisms. ${ }^{14}$ These segmented networks push the internet to become increasingly endogenous to the local context. ${ }^{15}$ Initial inroads into the effects of social media on violent collective action show that social media penetration generates substantial increases in violent collective action, especially in areas that lacked mass communication technologies prior to the introduction of social media. ${ }^{16}$ It is important to note that these effects are observed in areas where a history of armed conflict exists. The introduction of new communications does not mean a stable political situation will inherently descend into violence (think adding $5 \mathrm{G}$ technology into countries such as the United States and Germany).

The above work has established a baseline for ICTs' effect on violent collective action, but there are some limitations of the literature. These works might lead one to suspect that the number of peaceful and violent movements have increased with the introduction of advanced ICTs. Instead, it is the number of events within each conflict that has increased, not the number of conflicts, thus demonstrating the dichotomy between the macro and micro effects of ICTs. ${ }^{17}$ While the lack of data on rural cellular access might limit the findings of certain empirical studies, the various investigations in the field show strong evidence that ICTs can be used to increase violent collective action by reducing the cost of communication, increasing the volume of information shared, and massing disaggregated group members in an expedited manner. ${ }^{18}$

These studies have a few key implications. First, advances in ICTs can affect both political collective action and violent collective action. Groups can decide how to use ICTs to accomplish their objectives. Larger volumes of information can be shared to more nodes who are geographically disaggregated at a lower cost and within a shorter period. Second, the greatest effect on violent collective action can be observed in cases where an advancement in ICTs changes the nature of how nodes within a system communicate. Studies have demonstrated 
that increasing data rates (i.e., $3 \mathrm{G}$ to $4 \mathrm{G}$ ) do not lead to a statistically significant increase in violence.

Data rates can be conceptualized as changes in the character of communications as it might change different sites or data types that are transmitted. For example, moving from $3 \mathrm{G}$ to $4 \mathrm{G}$ means that users can post higher quality videos on social media sites. Videos with more detail transmit more information, which can be a change in the character of communication. However, moving from $3 \mathrm{G}$ to $4 \mathrm{G}$ does not make an individual use an inherently different system for communication, which would be a change in the nature of communication. They are still using the same, if maybe an updated version, of the social media site. Changes in the nature of communication are more indicative of evolutions that rearrange in a systematic way how nodes within a system are connected. Finally, advances in ICTs disproportionally benefit nonstate actors when compared to state actors. This is because before the proliferation of these technologies, most states have maintained a working communications system between nodes within the state, having the resources to invest in phone lines and military-style radio communications. These methodologies have historically been price prohibitive for nonstate actors. Cheap and effective ICTs have significantly closed this gap. When combined, these three findings indicate that advances in ICTs have a direct effect on how nodes within a system interact and thus will also affect the cycle of violent collective action experienced by these groups.

\section{Information-centric Approach to Warfare}

Information has always been a vital component of warfare. Yet, it has historically not been viewed as equivalent to other determinants of war outcomes. Early work on the concept of "netwar" focused on how insurgents, criminals, and social activists will use the growing information environment as its own conflict space. ${ }^{19}$ Factors such as natural resources, economic power, and military strength have been used by many to examine war outcomes of conflicts. However, information is an equally important component in the execution of war. The work of Eli Berman, Joseph H. Felter, and Jacob N. Shapiro is a notable empirical work that emphasizes the role of information in contemporary conflicts. ${ }^{20}$ The study introduces an information-centric approach to warfare, which they derive from their experience supporting operations in both Iraq and Afghanistan. One key insight of the study is that asymmetric conflicts like the complex intrastate conflicts described in the first section are inherently information-centric. In other words, the information environment is a key space of contestation between the conflicting parties. Each of the contending belligerent parties is trying to outmaneuver the other within the information realm to gain an advantage over the other.

Within an information-centric conflict, the key factor is the flow of in- 
formation. Economic or military capacity at the macro level will not have a substantive effect on the conflict outcome if the flow of information remains constant or is advantageous to an adversary at the local level. ${ }^{21}$ For this flow to be effective, it must be consistent and digestible by the intended audience. This approach is more relevant to the complex intrastate conflicts today, since battles are smaller in scale and local-level factors have a greater impact on the outcomes. ${ }^{22}$ As mentioned in the second section, access to advanced ICTs has direct consequence to the information-centric battlespace.

The amount of data being produced in the global south has grown at an exponential rate from the mid-2000s to the late $2010 \mathrm{~s} .{ }^{23}$ For example, India is creating the digital infrastructure to provide all of its 1.2 billion residents with a unique online identification. Myanmar, a country rife with internal violent conflicts, experienced a 50-fold increase in internet users from 2007 to 2014. Providers within the information space are therefore diverse not only in their numbers but also in the services they can provide. Even in conflict-torn Syria, a total of nine internet service providers expanded service by 1.6 million users between 2010 and 2016, demonstrating growth in a nation embroiled in a civil war. While this list is in no way exhaustive, it demonstrates that historically underdeveloped parts of the world are quickly experiencing a rapid increase in the availability of internet access. With the right penetration of internet connectivity and social media access, internal conflicts will be fought in the kinetic battle space as well as the information realm. This makes the information-centric approach to warfare applicable with the flow of information potentially being a key determinant of battlefield outcomes and how those outcomes are communicated to decision makers on both sides of the trenches. Before an examination of how the information-centric approach to war interplays with the likelihood of conflicting parties entering negotiations, it is important to understand the bargaining model of war.

\section{Bargaining Model of War}

Wars generally start when one group believes they have the necessary strength to extract concessions from another group through force. These demands can be for either territory, natural resources, political subjugation, or cultural differences. No matter what the nature of the dispute, war equates to groups using violent means against another group to change the status quo between them. This also means that war is an interaction between groups. It is through this violent interaction that groups begin to discover more about their opponent. Whether it be their relative strengths or the resolve to fight, battles expose information about a group's opponent. Examining wars from this bargaining model helps us understand how information flow is vital to outcomes like negotiated settlements. 
Dan Reiter's work into the bargaining model of war lays out a comprehensive understanding of how this interaction plays out in armed conflict. ${ }^{24}$ The main problem actors face is that they cannot all achieve their most desired goals simultaneously due to scarcity. This can be due to limited physical resources (e.g., oil), trying to maximize political support within a nation, or alignment of different leaders within a religious framework. The bargaining model sees the essence of conflict as a disagreement over resource allocation or policy choice. Thus, war happens because sides disagree about their ability to inflict unsustainable costs on their opponent while simultaneously absorbing costs imposed on themselves by the opponent to settle that disagreement over resource allocation. These wars emerge from the perceptual biases and miscalculations of each actor, who build their cost-benefit analysis based on their framing of the problem. This means that what might be costly to one actor is not a concern for another (i.e., cultural/religious differences). Interactions (kinetic and nonkinetic) between the adversaries reveals information about each other, causing expectations of the two sides to converge and opening up space for negotiation onset.

The work of Darren Filson and Suzanne Werner provides a more in-depth description of kinetic actions within the bargaining model of war. Using a causal chain of analysis, the authors argue that in a perceived equilibrium, an attacker never provokes a fight with a defender since the benefits of such adventurism tends to outweigh the costs. ${ }^{25}$ Wars only begin when the attacker believes they have an advantage over the defender and that they have the means to exploit those gaps. The attacker's private information about their chances of winning battles evolves in response to a defender's rejections of the attacker's demands. The defender's rejection is in turn informed by battlefield results and their own internal cost-benefit analysis of continuing to fight. This means that the private information about their own capability and their (one-sided) belief about their relative strength informs their next move. The revelation of mutual strength can reduce uncertainty, thus shortening war duration. ${ }^{26}$

Further work in the field has empirically reinforced the bargaining model of war presented by Filson and Werner. Information about relative military strength is a key driver during the mediation process, with intrastate conflicts between groups being the most likely to enter negotiations when they are at parity than groups with greater power asymmetry. ${ }^{27}$ Additionally, the location of battles also plays an important role in the calculus of parties. States are less likely to enter negotiations when the rebels are at the gates of the capital as the government knows that it is in a significantly weaker negotiating position. ${ }^{28}$ This was seen in the Libyan Civil War (2011-20), where the Government of National Accord (GNA) and Libyan National Army refused negotiations while Tripoli was under siege. It was not until the GNA's quick succession of bat- 
tlefield victories in early fall of 2020 that the sides agreed to enter into more substantial talks.

A leader's information concerning the population's willingness to continue fighting also impacts the duration of conflict. Research suggests that war weariness among the masses increases willingness for sides to enter negotiations. ${ }^{29} \mathrm{~A}$ common thread in all these critical group decisions to continue the war is the information environment. The murkier the waters, the harder it is for groups to resolve their uncertainty of the situation. Previous work has demonstrated that negotiations are less likely to happen when multiple actors join the fold, adding more uncertainty to the strategic calculations. ${ }^{30}$ While there are strong incentives for parties to misrepresent information (e.g., through misinformation campaigns) as long as that information is believed by the targeted party, it will still be used by them to shape their understanding of the battlespace. ${ }^{31}$ The bargaining model of war provides key insights into the factors that influence when parties will enter negotiations with their adversary. What is needed is a theoretical approach that combines the bargaining model of war presented by Filson and Werner with the new information environment that groups operate within during modern intrastate conflicts.

\section{Social Media and Likelihood of Negotiations}

Taking into account the discussion above, the author examined how social media and internet connectivity affects war decision making. This model is not meant to be universal in nature. The effects of social media penetration and internet connectivity vary depending on the type of conflict the actors are involved in. This model focuses on intrastate wars where the conflict takes on conventional characteristics and neither side has robust intelligence agencies. This is because actors with robust intelligence agencies would not rely on opensource reporting for the majority of their information. The model focuses on information instead of intelligence, since intelligence is information that has been evaluated, analyzed, and synthesized into a certain context. ${ }^{32}$ The conflict also needs to be conventional in nature, where both sides can control territory and deny the adversary access to that territory. This is important because the bargaining model of war breaks down once you move into conflicts where parties do not have some level of parity. Without near parity there is no true incentive for the powerful party to enter negotiations with the significantly weaker power.

Additionally, this model focuses on intrastate wars because in most of these conflicts the actors have the funds to sustain the above-mentioned intelligence capabilities. Actors are incentivized to use the internet and social media for a variety of reasons. First, it is the most immediate feed of information from all sides within a conflict. Groups will use it to monitor social media accounts of the opponents to try to gather exploitable information, which they can do easily 
since the service is inexpensive and mobile. This is negated when one state actor is able to impose a communications blackout on a region, similar to what has occurred in the 2020 Ethiopian-Tigray conflict. ${ }^{33}$ However, in some countries, control of the communications infrastructure is not as centralized, making it difficult for one side to institute a large-scale information blackout. Second, the internet and social media combine quick feedback of information that originates from multiple nodes in the system, thus providing an avenue to confirm information received from one source. ${ }^{34}$ It is important to keep in mind that this model does not take into account the effects of misinformation. This model is not focused on the flow of factually correct information. Instead, it focuses on the flow of information that can shift the mindset of influencers within each respective actors' system. As long as the actor believes the information to be true, that information will influence the actor's decision-making cycle.

Wars are a constant revolving interaction between actors. With this in mind, the following model can be deduced, explaining the interaction between the likelihood of negotiation onset, social media penetration, and internet connectivity. First, actor 1 uses the information they already have on actor 2's (the adversary) capabilities and limitations. Using that information, they make a demand of actor 2. Actor 2 then either has the option to give in to actor 1's demands or to deny them. If actor 2 gives in, the cycle is broken and the interaction ends. If actor 2 denies the demands, actor 1 has the option to either back out (maintaining the status quo) or to attack actor 2 to force them to capitulate. The two sides then take their dispute to the battlefield, where a complex series of variables clash violently with the outcome being unpredictable.

During the battle, both actors learn more about the capabilities and limitations of their adversary based on their battlefield performance. After the battle has concluded, both actors face another decision point. Actor 2 can either give in to the original demands of actor 1 or continue resistance. Actor 1 can either withdrawal their demands or continue with the same demands. If actor 2 continues resistance and actor 1 does not withdraw, then the cycle repeats with actor 1 making demands of actor 2 . This cycle takes a certain amount of time $(\mathrm{T})$, which varies based on battle duration, the initial interactions over demands, and how long it takes actors 1 and 2 to respond to the results of the battle. With an updated picture of the adversary's abilities, revealed through battle, actor 1 can either sustain their current demands or adjust them based on the new operational picture. At each point in the cycle, either actor 1 or 2 can decide to enter negotiations, trying to reach a middle ground between actor 1's demands and actor 2's rejection of any concessions. As the conflict continues, this cycle is repeated, and the actors get closer to reaching information certainty. It is important to note that neither actor can ever reach true information certainty, as the chaotic nature of war always leaves information unknown to both 
Figure 1. Bargaining model cycle

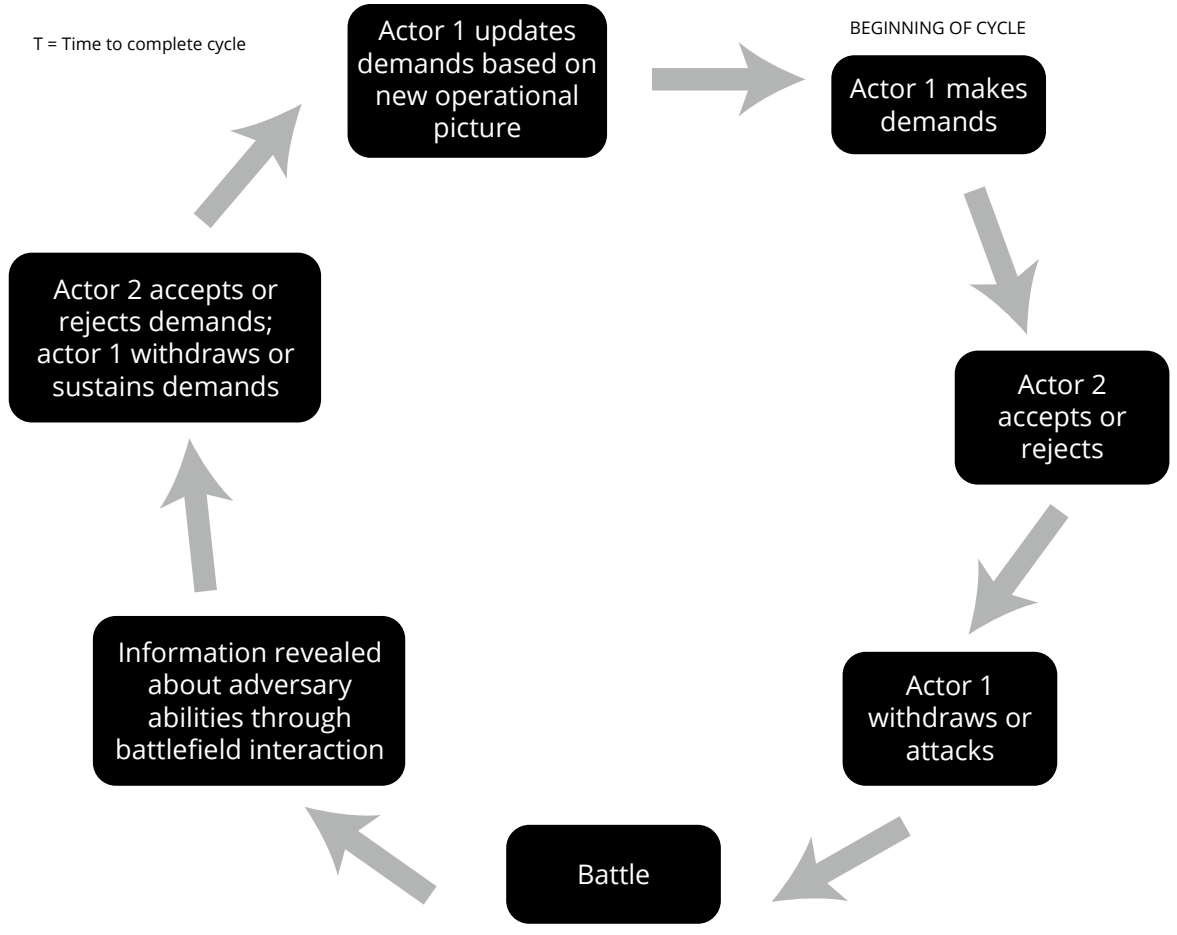

Source: Courtesy of author, adapted by MCUP.

actors. However, the closer the actors get toward this level of perfect knowledge, the better informed their decision-making process will become. Greater information certainty will allow each actor to understand what end state they can likely achieve based on the power dynamics between them. If both actors conclude that complete victory is unlikely, they will attempt to enter negotiations with their adversary. This will be required to obtain their most desired end state within the conflict since neither side can force all of their demands on their adversary.

Figure 1 depicts how the bargaining model of war can operate as a cycle, with battles revealing information that forces leaders to reevaluate their decision making. Modern intrastate wars that take on conventional characteristics operate in a similar manner. However, the introduction of social media penetration (SP) and internet connectivity (IC) expedite this process. The first half of figure 2 remains the same. Where SP and IC start to influence the system is after the battle. The combined effect of SP and IC increases the value of the perception of the adversary's capabilities and limitations. Various nodes in an interconnected information system reveal more information to actor 1 and actor 2 and provide verification mechanisms that strengthen those perceptions of the adversary's capabilities and limitations. Additionally, since SP and IC allow actors 1 
Figure 2. Impacts of internet connectivity and social media penetration on the bargaining model cycle

$\mathrm{T}(\mathrm{I} / \mathrm{IC} \star \mathrm{SP})=$ Time to complete cycle

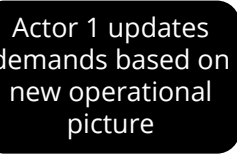

Actor 2 accepts or

rejects demands;

actor 1 withdraws or

sustains demands
Actor 2 accepts or rejects
Information revealed about adversary abilities through battlefield interaction; information increases as SP and IC within combat zone increase

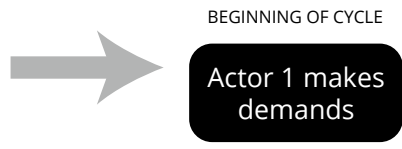

\section{Battle}

Actor 1

withdraws or attacks

Source: Courtesy of author, adapted by MCUP.

and 2 to obtain clearer pictures of the true capabilities and limitations of their adversary, they hasten the decision-making cycle of actors 1 and 2 and reduce the time it takes for each cycle to complete. Since actors 1 and 2 can complete more cycles in a shorter period of time, it theoretically increases the likelihood that actors 1 and 2 will enter negotiations within a given time frame since it closes the information gap between both sides and limits uncertainty.

After running through this model, there are two hypotheses that can be tested in future empirical work:

H1: Higher levels of social media penetration and internet connectivity increase the likelihood that conflicting parties will enter negotiations.

H2: The effects of social media access on the likelihood of a dyad entering negotiations decreases over time as the number of active rebel groups in a conflict zone increases.

$\mathrm{H} 1$ focuses on the main topic of this article. $\mathrm{H} 2$ expands on $\mathrm{H} 1$ by taking into account complex conflicts where multiple disaggregate parties battle each 
other in a conventional style (e.g., the Syrian Civil War [2011-present], First Congo War [1996-97], and the Libyan Civil War). While more actors within the system increase the flow of information, the myriad of sources and competing dyads muddies the information waters, thus reducing the effects of SP and IC. H1 was selected because it is the most directly testable hypothesis pulled from the aforementioned model. $\mathrm{H} 2$ was selected to allow for an additional testable hypothesis that specifically takes into account multifaceted intrastate conflict. These hypotheses provide a baseline for future empirical testing.

\section{Conclusion}

The introduction of new communications technologies has altered the way humans interact. Violent political collective action has also been affected by these advances. Understanding how these technologies affect intrastate wars can have important policy implications. For example, nongovernmental organizations may change the way they interact with parties within a conflicting dyad. If they know that social media access helps the sides enter negotiations faster, they may try to invest in reporting methodologies to decrease decision-maker uncertainty within the information space. For government agencies, knowing which information sources influence decision makers within a conflicting dyad can give the government another avenue to push parties toward maintaining the status quo or entering negotiations before a war even starts by reducing decision-maker uncertainty. The gathering, analysis, and spread of information is a vital part of modern-day conflict.

This article aimed to lay out an explanatory model for how social media penetration and internet connectivity can increase the likelihood of actors entering negotiations by reducing the amount of time it takes for both actors to close their information gaps. The next step in the research process is to test this model empirically. Expected challenges involve measuring internet connectivity, measuring social media penetration, defining intrastate conventional conflicts with quantitative measures, controlling for confounding variables, and defining negotiation onset. A better understanding of how the evolving communications landscape interplays with intrastate conflict is important to inform policy makers on how best to allocate resources toward certain lines of effort.

\section{Endnotes}

1. "FARC," Uppsala Conflict Data Program, accessed 8 February 2021; and Alexandre Marc, Conflict and Violence in the 21st Century: Current Trends as Observed in Empirical Research and Statistics (Washington, DC: World Bank Group, 2015).

2. Timothy R. Heath, China's Pursuit of Overseas Security (Santa Monica, CA: Rand, 2018), https://doi.org/10.7249/RR2271; Nakissa Jahanbani, "Reviewing Iran's Proxies by Region: A Look Toward the Middle East, South Asia, and Africa," CTC Sentinel 
13, no. 5 (May 2020); and Candace Rondeux and David Sterman, Twenty-First Century Proxy Warfare: Confronting Strategic Innovation in a Multipolar World (Washington, DC: New America, 2019).

3. Maj Amos C. Fox, USA, In Pursuit of a General Theory of Proxy Warfare, Land Warfare Paper 123 (Arlington, VA: Institute of Land Warfare, 2019).

4. "Syria Situation Report: January 8-29, 2021," understandingwar.org, 29 January 2021; and Alia Chughtai and Ramy Allahoum, "Libya: Mapping Areas of Military Control," Al Jazeera, 27 July 2020.

5. "Worldwide Digital Population as of October 2020," Statista, 27 January 2021.

6. Anita Breuer, Todd Landman, and Dorothea Farquhar, "Social Media and Protest Mobilization: Evidence from the Tunisian Revolution," Democratization 22, no. 4 (2015): 764-92, https://doi.org/10.1080/13510347.2014.885505.

7. Mancur Olson, The Logic of Collective Action: Public Goods and the Theory of Groups (Cambridge, MA: Harvard University Press, 1965).

8. Ruben Enikolopov, Alexey Makarin, and Maria Petrova, "Social Media and Protest Participation: Evidence from Russia," Econometrica 88, no. 4 (2020): 1479-1514, https://doi.org/10.3982/ECTA14281.

9. George Barros, "Warning: Kremlin-linked Belarusian Opposition Leadership Threaten to Further Fragment Opposition Unit," Institute for the Study of War, 1 September 2020; and Zachary C. Steinert-Threlkeld et al., "Online Social Networks and Offline Protest," EPJDataScience 4, no. 19(2015):4-19, https://doi.org/10.1140/epjds/s13688 -015-0056-y.

10. T. Camber Warren, "Not by the Sword Alone: Soft Power, Mass Media, and the Production of State Sovereignty," International Organization 68, no. 1 (2014): 111-41, https ://doi.org/https://doi.org/10.1017/S0020818313000350; and David YanagizawaDrott, "Propaganda and Conflict: Theory and Evidence from the Rwandan Genocide" (working paper, Center for International Development at Harvard University, Cambridge, MA, 2012).

11. Jan H. Pierskalla, and Florian M. Hollenbach, "Technology and Collective Action: The Effect of Cell Phone Coverage on Political Violence in Africa," American Political Science Review 107, no. 2 (May 2013): 207-24, https://doi.org/10.1017 /S0003055413000075.

12. It is important to note that ICTs do not begin this cycle as there are many other conditions that interplay during conflict onset. Ted Gurr, "Psychological Factors in Civil Violence," World Politics 20, no. 2 (January 1968): 245-78, https://doi .org/10.2307/2009798, provides a good look into the psychology of conflict onset.

13. Catie Snow Bailard, "Ethnic Conflict Goes Mobile: Mobile Technology's Effect on Opportunities and Motivations for Violent Collective Action," Journal of Peace Research 52, no. 2 (2015): 323-37, https://doi.org/10.1177/0022343314556334.

14. Thomas Zeitzoff, "How Social Media Is Changing Conflict," Journal of Conflict Resolution 1, no. 22 (2017), https://doi.org/10.1177/0022002717721392.

15. Anita R. Gohdes, "Studying the Internet and Violent Conflict," Conflict Managementand Peace Science 35, no. 1 (2018): 89-106, https://doi.org/10.1177/0738894217733878.

16. T. Camber Warren, "Explosive Connections?: Mass Media, Social Media, and the Geography of Collective Violence in African States," Journal of Peace Research 52, no. 3 (2015): 297-311, https://doi.org/10.1177/0022343314558102.

17. Erica Chenoweth and Maria Stephan, Why Civil Resistance Works: The Strategic Logic of Nonviolent Conflict (New York: Columbia University Press, 2011).

18. Allan Dafoe and Jason Lyall, "From Cell Phones to Conflict?: Reflections on the Emerging ITC Political Conflict Research Agenda," Journal of Peace Research 52, no. 3 (May 2015): 401-13, https://dx.doi.org/10.2139/ssrn.2409639.

19. John Arquilla and David Ronfeldt, Networks and Netwars: The Future of Terror, Crime, and Militancy (Santa Monica, CA: Rand, 2001), https://doi.org/10.7249/MR1382. Netwar was first defined by Rand as a "societal conflict and crime, short of war, in which the antagonists are organized more as sprawling 'leaderless' networks than as tight-knit hierarchies." 
20. Eli Berman, Joseph H. Felter, and Jacob N. Shapiro, Small Wars, Big Data: The Information Revolution in Modern Conflict (Princeton, NJ: Princeton University Press, 2018).

21. Berman, Felter, and Shapiro, Small Wars, Big Data.

22. Lotta Themnér and Peter Wallensteen, "Armed Conflicts, 1946-2013," Journal of Peace Research 51, no. 4 (2014): 541-54, https://doi.org/10.1177/0022343314542076. Note: the observance of lower battle being smaller in scale is due to the observed increase in armed intrastate conflicts that corresponds with an observed decrease in battle-related fatalities, meaning that less people are dying in an expanding series of armed conflicts.

23. Paya Arora, "The Bottom of the Data Pyramid: Big Data and the Global South," International Journal of Communication, no. 10 (2016): 1681-99.

24. Dan Reiter, "Exploring the Bargaining Model of War," Perspectives on Politics 1, no. 1 (March 2003): 27-43, https://doi.org/10.1017/S1537592703000033.

25. Darren Filson and Suzanne Werner, "A Bargaining Model of War and Peace: Anticipating the Onset, Duration, and Outcome of War," American Journal of Political Science 46, no. 4 (October 2002): 819-37, https://doi.org/10.2307/3088436.

26. Govinda Clayton, "Relative Rebel Strength and the Onset and Outcome of Civil War Mediation," Journal of Peace Research 50, no. 5 (2013): 609-22, https://doi .org/10.1177/0022343313491587.

27. Philip Hultquist, "Power, Parity, and Peace?: The Role of Relative Power in Civil War Settlement," Journal of Peace Research 50, no. 5 (2013): 623-34, https://doi.org /10.1177/0022343313486281; J. Michael Greig, "Nipping Them in the Bud: The Onset of Mediation in Low-Intensity Civil Conflicts," Journal of Conflict Resolution 59, no. 2 (2015): 336-61, https://doi.org/10.1177/0022002713503807; and David E. Cunningham, Kristian Skrede Gleditsch, and Idean Salehyan, "It Takes Two: A Dyadic Analysis of Civil War Duration and Outcome," Journal of Conflict Resolution 53, no. 4 (2009): 570-97, https://doi.org/10.1177/0022002709336458.

28. Sema Hande Ogutcu-Fu, "Outside the Battlefield: In-Group Political Dynamics of Civil Conflict Negotiations and Settlements," Political Science Quarterly 69, no. 3 (2016): 403-17, https://doi.org/10.1177/1065912916648010.

29. David E. Cunningham, "Veto Players and Civil War Duration," American Journal of Political Science 50, no. 4 (October 2006): 875-92, https://doi.org/10.1111/j.1540 -5907.2006.00221.x.

30. Desiree Nilsson, "Turning Weakness into Strength: Military Capabilities Multiple Rebel Groups and Negotiated Settlements," Conflict Management and Peace Science 27, no. 3 (2010): 253-71, https://doi.org/10.1177/0738894210366512.

31. Dafoe and Lyall, "From Cell Phones to Conflict?," 401-13.

32. Intelligence, Marine Corps Doctrinal Publication 2 (Washington, DC: Headquarters Marine Corps, 2018). Recent scholarship has found a statistically insignificant relationship between external provision of intelligence and conflict termination. See Katherine Sawyer, Kathleen G. Cunningham, and William Reed, "The Role of External Support in Civil War Termination,” Journal of Conflict Resolution 6, no. 61 (2017): 1174-1202, https://doi.org/10.1177/0022002715600761.

33. Following a disputed federal and regional elections process in the summer and fall of 2020, the Ethiopian government and regional government of Tigray opened kinetic hostilities with each other. On 4 November, the Ethiopian government blocked out the majority of communications within the region, making it incredibly difficult for outsiders to get information on troop movements and battlefield results.

34. Bailard, "Ethnic Conflict Goes Mobile," 323-37. This theory at first glance appears to be in contention with the work of Bailard, whose findings indicate that an increase in cell service increased the probability of violent conflict between rebels and the government. However, this theory examines how social media penetration and internet connectivity affect the likelihood of negotiation onset. The same technology that groups use to mobilize supports before and during conflict onset can also be used for information collection (as examined earlier). 